\title{
KATOLIČKI SASTANCI U SPLITU U KOLOVOZU 1908. I 1909. GODINE
}

\author{
Mate Anić
}

Sveučilište u Splitu Filozofski fakultet mateanic2@gmail.com
UDK: 272-662:3](497.583Split)“1908/1909“ https://doi.org/10.34075/cs.56.2.7 Pregledni znanstveni rad Rad zaprimljen 7/2020.

\section{Sažetak}

Rad prikazuje razvoj Hrvatskoga katoličkog pokreta do rujna 1909., s posebnim naglaskom na katoličke sastanke u Splitu u kolovozu 1908. i 1909. godine. U Splitu su u kolovozu 1908. održana tri sastanka: đački (pitanja Hrvatskoga katoličkog pokreta), katehetski (stanje školstva u Dalmaciji) i katehetski tečaj (metode poučavanja u teoriji i praksi). Sljedeće godine u kolovozu održan je Sveđački katolički sastanak u Splitu. koji označava prekretnicu u Katoličkom pokretu na području Hrvatske. Rad se posebice osvrće na važnost Sveđačkog sastanka te ga vrednuje u širem kontekstu Hrvatskoga katoličkog pokreta. Važnost tog sastanka sastoji se u tome što je označio početak nove faze Katoličkog pokreta na području Hrvatske, tj. došlo je do omasovljenja Pokreta. Temeljni izvor za izradu radajest splitski katolički list Dan (1903. - 1918.).

Ključne riječi: Hrvatski katolički pokret, Split, đački i katehetski sastanak, katehetski tečaj, Sveđački katolički sastanak

\section{UvOD}

Katolički pokret javlja se u Europi u 19. stoljeću kao odgovor katoličkih laika na radikalnija liberalna strujanja i učestale napade pojedinih liberalnih skupina na Crkvu te na jačanje materijalističkoga i pozitivističkoga mentaliteta koji je katoličku vjeru svodio na razinu praznovjerja. Razlika između katoličkih pokreta u Europi i Katoličkog pokreta na području Hrvatske leži u tome što je Hrvatski katolički pokret (dalje: HKP) bio prožet potrebom za ujedinjenjem hrvatskih zemalja, tj. nacionalna osnova jedan je od temelja HKP-a. Početak katoličkog pokreta na području Hrvatske vezan je za početak organiziranja katoličkih laika na poticaj krčkog biskupa 
Antuna Mahnića ${ }^{1}$. Bez obzira što je pokret načelno bio laički, veliku ulogu u njemu imali i svećenici. Utjecaj Mahnićevih ideja dopirao je do Beča, gdje je jedan od njegovih učenika, krčki svećenik Ivan Butković, uz još nekolicinu drugih studenata osnovao Hrvatsko katoličko akademsko društvo Hrvatska (dalje: HKAD Hrvatska). Za razliku od već postojećega hrvatskog studentskog društva Zvonimir u Beču, koje je bilo prožeto nacionalnim obilježjima bez vjerskog angažmana, HKAD Hrvatska je uz nacionalne, naglašavao i katoličke vrijednosti. Dvije godine nakon osnivanja HKAD Hrvatska počeo je izdavati list za katoličko đaštvo pod nazivom Luč. Glavne značajke lista $L u \check{c}$, ali i samog đačkog pokreta oko lista temeljile su se na vjeri (katoličanstvo), narodnosti (hrvatstvo) te demokraciji (kršćanskoj). ${ }^{2}$

Cilj ovog rada je rasvijetliti ulogu katoličkih sastanaka u Splitu u kolovozu 1908. i Sveđačkog katoličkog sastanka u kolovozu 1909. godine. U literaturi o HKP-u ljeto 1908. spominje se kao razdoblje u kojem su diljem Hrvatske održani ferijalni sastanci (Đakovo, Zagreb, Trsat, Split i Travnik). Stoga će se ovaj rad baviti ferijalnim sastankom u Splitu, ali i katehetskim sastankom i katehetskim tečajem koji su se održavali dan nakon završetka ferijalnog sastanka. Sva tri sastanka govore barem o jednom dijelu razvoja HKP-a, nacionalnom i regionalnom te njihovoj međusobnoj komunikaciji. Rad će se ukratko osvrnuti na katolički sastanak na Trsatu 1906., a zatim Sveđački katolički sastanak u Zagrebu 1907. godine. Cilj kratkog opisa ovih sastanaka jest bolje razumijevanje okolnosti koje su dovele do sastanaka u ljeto 1908. i 1909. godine. Zatim će uslijediti kratak prikaz i vrednovanje tema i problema koji se iznose na sastancima u Splitu u kolovozu 1908. i 1909. te koji su ujedno i odraz cjelokupnog programa HKP-a. U literaturi o HKP-u spominje se da je na Sveđačkom katoličkom sastanku 1909. sudjelovalo oko 800 sudionika iz cijele Hrvatske, Slovenije, Bosne i Hercegovine te da je nakon tog sastanka osnovan Hrvatski katolički đački savez. Stoga će ovaj rad, između ostalog, detaljnije opisati i analizirati Sveđački sastanak u Splitu sa svrhom vrednovanja tog sastanka u smislu njegova doprinosa razvoju HKP-a. Kao glavni izvor za izradu rada korišteno je katoličko glasilo Dan, koje je izlazilo u Splitu od 1903. do 1918. godine.

1 Više o biskupu Antunu Mahniću i njegovim idejama vidi u: Anton Bozanić, Biskup Antun Mahnić: čovjek nepokolebljive vjere, jasnih vizija i smjelih djela, Kršćanska sadašnjost, Zagreb, 2013.

2 Jure Krišto, Hrvatski katolički pokret, Glas Koncila - Hrvatski institut za povijest, Zagreb, 2004., str. 33-41; Jure Krišto, Prešućena povijest: Katolička crkva u hrvatskoj politici 1850.-1918., Hrvatska sveučilišna naklada, Zagreb, 1994., str. 195-199. 


\section{KATOLIČKI ĐAČKI SASTANAK NA TRSATU KOD RIJEKE 1906. GODINE}

Među prvim važnim sastancima u vezi s razvojem HKP-a potrebno je istaknuti trsatski sastanak, održan od 21. do 23. kolovoza 1906., na kojem se okupilo oko 50 ljudi, uglavnom studenata bogoslovlja iz Zagreba i Slovenije. Na sastanku je glavna tema bila organizacija katoličke mladeži na socijalnom, kulturnom i političkom polju. Unutar ovih tema raspravljalo se "o dobroj i zloj štampi“, zato što „napisane riječi lako izginu, ali ideje ostaju stalne“" ${ }^{\text {. Zaključci }}$ doneseni na sastanku uključuju suzbijanje "zle" štampe te promoviranje lista Luč i pretplatu na taj list, osnivanje kongregacija u srednjim školama, osnivanje Hrvatskog akademskog katoličkog društva u Zagrebu (po uzoru na HKAD Hrvatska u Beču), poticaj da se katolički đaci udružuju u razna društva te da se naposljetku udruže u jedan "Savez katoličkog đaštva". Zadnja rezolucija odnosi se na kulturno i socijalno djelovanje hrvatskih bogoslova, koje obuhvaća tri područja: gospodarsku organizaciju, narodnu prosvjetu i apologetski studij. ${ }^{4}$

Sastanak je označio početak organizacije katoličke mladeži na području Hrvatske. Rezolucija o osnivanju HKAD-a u Zagrebu provedena je iste godine u studenome, kada je osnovan HKAD Domagoj. ${ }^{5}$

\section{PRVI HRVATSKO-SLOVENSKI SVEĐAČKI KATOLIČKI SASTANAK 1907. GODINE}

Nakon trsatskog sastanka je, kako je i planirano, održan Katolički đački sastanak u Zagrebu, od 4. do 6. kolovoza 1907. godine, koji je okupio oko 400 sudionika. ${ }^{6}$ Među važnim točkama sastanka izdvaja se predavanje dr. Janeza Kreka o kršćansko-

3 Dan, god. IV. br. 33., Split, 1906., str. 3.

4 Isto, str. 2-3.

5 Vidi više o osnivanju HKAD-a Domagoj: Ivan Butković, „Glavni momenti u pokretu hrvatskoga katoličkoga narodnoga đaštva“, Koledar hrvatskoga katoličkoga narodnoga đaštva za školsku godinu 1909/10, (ur. Velimir DEŽELIĆ), Hrvatsko katoličko akademsko društvo Domagoj, Zagreb, 1909., str. 90-91; Luka Perinić, Iz moje ladice, HKD sv. Jeronima, Zagreb, 2009., str. 36-37; Velimir Deželić ml., Kakvi smo bili? Zapisi mojoj unučadi: život zagrebačke obitelji od 1827. do 1953., knjiga 1, Naklada družba „Braća hrvatskoga zmaja“, Zagreb, 2011., str. 511.

6 Vidi više: Luč, god. III, br. 1, 1907., str. 30-31; Petar Grgec, Dr. Rudolf Eckert, Hrvatsko književno društvo Sv. Ćirila i Metoda (Sv. Jeronima), Rijeka, 1995., str. 45-46 
socijalnim idejama. ${ }^{7} \mathrm{U}$ rezolucijama se spominje zahtjev za većom naobrazbom srednjoškolaca u vjerskim pitanjima te potreba bavljenja znanstvenom lektirom koja će se čitati u literarnim društvima. Srednjoškolci ce svoje radove slati uredništvima listova Luč i Hrvatska straža. Ujedno, pozivaju se đaci da stupe u Marijine kongregaci$\mathrm{je}^{8}$. Važno je istaknuti rezoluciju VI., točku 3., prema kojoj je poželjno da bogoslovi pohađaju katehetsko-apologetske tečajeve u drugim zemljama, ali i da se takvi tečajevi održe i na području Hrvatske. ${ }^{9}$ Takvi tečajevi održani su u ljeto 1908. godine. Najvažnija rezolucija ovog sastanka je odluka o organizaciji đaka srednjih škola koja je trebala započeti početkom nove školske godine. Program se sastoji od četiri točke: „srednje škole, visoke škole, ženski katolički pokret i još jedan novi list". ${ }^{10}$ Posljednja rezolucija ovog sastanka odnosi se na odanost Svetoj Stolici i borbu protiv duha modernosti i njegovom negativnom utjecaju na mladež. ${ }^{11}$ Svrha sastanka bila je "poticaj za učvrščenje i rast pokreta u svim hrvatskim zemljama“. ${ }^{12}$

Splitski Dan piše kako se na sastanku došlo do spoznaje kako „zamišljaj organizacije nijesu kule u zraku, već da će se intenzivnim radom i to moći izvršiti“. ${ }^{13}$ Ovaj sastanak izazvao je lančanu reakciju, koja je dovela do pojačanog organiziranja katoličkog đaštva u idućim godinama. Primjerice, u Dalmaciji, u Zadru, već je nakon tri mjeseca od sastanka osnovan "Centralni odbor", koji je služio za organizaciju hrvatskoga katoličkoga đaštva u Dalmaciji. Uz bečku Hrvatsku i zagrebački Domagoj Zadar je tako postao treća organizirana skupina u Hrvatskom katoličkom pokretu. ${ }^{14}$

Početkom školske godine, u rujnu 1907., započeo je pojačani rad na organiziranju katoličkog đaštva, što će ujedno biti jedan od razloga organiziranja čak pet pokrajinskih sastanaka u ljeto 1908.

7 Vidi: Luč, god. III, br. 3, 1907., str. 278-283.

8 Kongregacije su duhovne udruge koje su služile za promicanje duhovnoga kršćanskog života među katoličkom mladeži, ali i odraslima. Postojale su srednjoškolske i akademske kongregacije. Glavne smjernice Kongregacija bile su pobožni život, vlastita naobrazba, literarni rad, tisak, pučka prosvjeta, apologetika, odmor i zabava. Vidi: Luč, god. II, br. 6, 1907., str. 182-187.

9 Dan, god. V, br. 33, Split, 1907., str. 1.

10 Vidi više: Luč, god. III, br. 1, 1907., str. 1-7; Anton Bozanić, „Djelovanje biskupa Mahnića na formaciji i organizaciji katoličkog laikata do 1912. godine“, Hrvatski katolički pokret. Zbornik radova s Međunarodnog znanstvenog skupa održanog u Zagrebu i Krku od 29. do 31. ožujka 2001. (dalje: HKP: zbornik radova), (ur. Zlatko Matijević), Kršćanska sadašnjost, Zagreb, 2002., str. 282.

11 Dan, god. V, br. 33, Split, 1907., str. 1.

12 J. Krišto, Hrvatski katolički pokret, str. 50.

13 Dan, god. VII, prilog broju 30, Split, 1909., str. 2.

14 Isto, str. 2. 
godine: u Đakovu, u Zagrebu, na Trsatu, u Splitu, u Travniku. Ferijalne sastanke dogovorili su i organizirali: HKAD Hrvatska, HKAD Domagoj i Centralni pokrajinski odbor u Zadru. Jedna od tema ovoga rada jest upravo jedan od tih pet ferijalnih sastanaka, onaj koji je održan u Splitu u kolovozu 1908. godine.

\section{KatoličKi SASTANCI u Splitu u Kolovozu 1908. godine}

Uoči održavanja sastanaka politička situacija u Splitu odvijala se oko tri glavne političke struje: starčevićanske, naprednjačke i klerikalne. "Starčevićanska" politička struja bila je najbrojnija, a tijekom godina podijelila se na naprednjake i katolike, zbog različitih stavova o kulturnim problemima, dok je politička ideja ostala nepromijenjena. Naprednjaci su uglavnom pridošlice sa stranih sveučilišta koji donose „nove, napredne, liberalne i slobodoumne ideje“. ${ }^{15}$ Oni su bili najveći neprijatelji klerikalaca, koji su treća najjača struja u Splitu. Naziv "klerikalci” odnosio se na klerike i laike koji su bili društveno angažirani u rješavanju aktualnih problema oslanjajući se na kršćanska načela, te su bili u sukobu s liberalnim strujanjima. Važno je naglasiti da se to nije odnosilo na sve svećenike, jer je dio svećenika bio u strankama koje su u načelu liberalne. Taj su naziv klericima i laicima dodijelili naprednjaci i njihova glasila. ${ }^{16}$

Hrvatsko katoličko đaštvo bilo je dobro upoznato s programom naprednjaka i njihovim kritikama. Upravo je zato katoličko đaštvo vodilo borbu na kulturnom polju, umjesto na političkom, kako bi se lakše oduprlo kritikama naprednjaka. Kulturna borba većinom se vodila preko članaka u novinama i putem tiskanja programatskih brošura. Tijekom održavanja raznih katoličkih sastanaka diljem Dalmacije u prvom desetljeću 20. stoljeća uvijek se u "naprednjačkim“ glasilima može pročitati riječ "klerikalci” ili "furtimaši”. Važno je naglasiti da "naprednjaci“ nisu bili protiv vjere općenito, nego protiv katoličke vjere i talijanskog Rima. Tako smatraju da je Crkva u Hrvatskoj protunarodna i anacionalna, pa čak i antidemokratska. Stoga je cilj naprednjaka bilo stvaranje "narodne Crkve“ po uzoru na Srpsku pravoslavnu Crkvu, koju su ujedno i zagovarali. ${ }^{17}$ Upravo je ta "kulturna borba" između "naprednjaka" i "klerikalaca" glavno obilježje stanja u Dalmaciji početkom 20. stoljeća.

U kontekstu katoličkih sastanaka u Splitu potrebno je osvrnuti se na postojeće stanje katoličke mladeži i događanja u Spli-

15 Luč, god. IV, br. 1, 1908., str. 48.

16 Jure Krišto, „Naprednjačka kritika katolištva“, HKP: zbornik radova, str. 293-297.

17 Isto, str. 293-297. 
tu neposredno prije održavanja sastanaka. Iz pisma ${ }^{18}$ Biskupskog sjemeništa u Splitu iz svibnja 1908. doznajemo kako već dvije godine u Sjemeništu postoji literarno društvo Neven, kojem je svrha vježbanje pisanja i retorike. Društvo se u početku sastojalo od samo šest članova, zbog čega se javila potreba za njegovim proširenjem. Stvara se ideja da se održe predavanja o raznim aktualnim pitanjima za klerike viših razreda kako bi se razvila debata i plodonosan razgovor. No ta ideja nije ostvarena u sklopu Sjemeništa, već u dogovoru s klericima izvan Nevena. Tako dolazi do organiziranja prvih sastanaka, na kojima se raspravlja o socijalnoj i kršćanskoj demokraciji te važnosti održavanja ovih sastanaka u budućnosti. Dogovoreno je da će se ovaj tip sastanka održavati jednom mjesečno i da će se zaključci sastanaka objavljivati u glasilu hrvatskoga katoličkog đaštva Luč. Sastancima je često pribivao isusovac Ante Alfirević ${ }^{19}$, prvak HKP-a i blizak suradnik biskupa Mahnića. On je ujedno jedan od najzaslužnijih za održavanje Sveđačkog sastanka u Splitu 1909. godine. ${ }^{20}$ Potrebno je izdvojiti raspravu o prosvjeti i gospodarstvu na literarnim sastancima jer ona rasvjetljava razvoj kulture i prosvjete preko tamburaških sastava i pjevačkih zborova, predstava, predavanja, rada knjižnica itd. ${ }^{21}$

Iz navedenog je razvidan početak organiziranja katoličke mladeži u Splitu uz pomoć pojedinih splitskih svećenika, posebice istaknutog Ante Alfirevića. Odluku o osnivanju literarnog društva Neven te odluku o održavanju literarnih sastanaka možemo pratiti od zaključaka Prvoga katoličkog sastanka 1906. na Trsatu. Upravo je komunikacija, primarno preko glasila katoličkog đaštva Luč, odigrala presudnu ulogu u organiziranju đačkih sastanaka. Zaključci sastanaka su, kako što je već rečeno, objavljivani u Luči, gdje su ih mogli pročitati svi pretplatnici lista.

Đački sastanak u Splitu (1. - 2. kolovoza) bio je jedan od pet đačkih sastanaka (Zagreb, Trsat, Đakovo i Travnik). Ti sastanci bili su uvod za veliki Sveđački sastanak koji će se održati u Splitu 1909. i okupiti 751 sudionika. Drugi sastanak, održan 4. i 5. kolovoza, okupio je vjeroučitelje i dušobrižnike iz cijele Dalmacije koji poučavaju nauk vjere. Prvi takav sastanak održan je u Splitu u kolovozu 1907. i okupio je katehete iz pučkih i srednjih škola, koji su raspravljali

18 Vidi: Luč, god. III, br. 1, 1908., str. 57-59.

19 Vidi više o Anti Alfireviću u: Slavko Kovačić, „Dr. Ante Alfirević - podrijetlo, školovanje i djelovanje do ulaska u Družbu Isusovu“, Zbornik radova sa znanstvenog skupa „Dr. Ante Alfirević, život i djelo“, Bijaći - društvo za očuvanje kulturne baštine Kaštela, Kaštel Kambelovac, 2016.

20 Vidi: Isto, str. 47.

21 Luč, god. III, br. 1, 1908., str. 57-58. 
o pitanjima vjere i poučavanju vjeronauka. Ujedno, na tom je sastanku odlučeno da se dogodine pozovu svi vjeroučitelji koji su u stanju doći u Split kao središte Dalmacije. Odmah nakon sastanka održan je katehetski tečaj, 6. i 7. kolovoza, koji je organiziralo nekoliko vjeroučitelja i pedagoga iz sjeverne Hrvatske. Glavne teme tečaja bile su školske prilike u Dalmaciji i ćudoredni odgoj u školama. ${ }^{22}$

\subsection{Pokrajinski hrvatski katolički đački sastanak u Splitu}

Prvi sastanak, održan 1. i 2. kolovoza 1908., đački je sastanak koji je okupio katoličku mladež iz Dalmacije. ${ }^{23}$ Teme su se uglavnom odnosile na vjeru i prosvjetu te na prijedloge o poboljšanju prosvjete. Unutar prosvjete raspravljalo se o već spomenutom literarnom društvu i đačkoj izobrazbi. Drugoga dana bila je riječ o tisku te Marijinim kongregacijama i srednjim školama. ${ }^{24}$ Marijine kongregacije i srednje škole bile su popularna tema općenito u HKP-u. ${ }^{25} \mathrm{Na}$ sastanku koji je održan u foyeru Kazališta u Splitu sudjelovalo je oko 120 đaka srednjih i viših škola. Osim đaka iz Dalmacije sudjelovalo je i nekoliko đaka s područja Banske Hrvatske, Istre te Bosne i Hercegovine, pa čak i jedan Poljak. ${ }^{26}$ Glasilo Dan iznosi kako je sastanak nadmašio očekivanja te da su teme stručno održane uz kvalitetnu raspravu. Nedugo nakon sastanka stiglo je nekoliko brzojava i čestitki iz cijele Hrvatske. ${ }^{27}$ Jedan đak sudionik sastanka rekao je sljedeće: „Kad nas je samo deset, deset nas je iste misli, dok naših protivnika, kad je stotina, nijesu niti dvojica, jer svaki misli drukčije."28

Svrha ovog sastanka bila je međusobno upoznavanje katoličkih đaka iz Dalmacije i ostatka Hrvatske te sagledavanje problema s kojim se susreću u školstvu. Na sastanku se razvija osjećaj za suradnju i povjerenje među đacima. Sastanak je završio pjevanjem državne himne, a zatim je uslijedilo simbolično razgledavanje Salone i njezinih građevina iz doba ranog kršćanstva. Đaci su raspravljali o problemima s kojima su se u to doba suočavali kršćani. Poseban pozdrav upućen je don Frani Buliću, koji je svojim znanstvenim radom proslavio hrvatsko ime. ${ }^{29}$

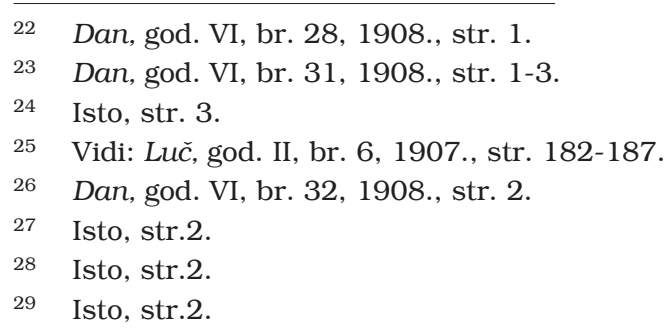


Temeljna postavka ovog ferijalnog sastanka, ali i ostalih ferijalnih sastanaka u ljeto 1908. jest kultura kao temelj iz kojega započinje djelovanje HKP-a. Tako se i na splitskom sastanku može iščitati kulturno obilježje iz triju glavnih stavki rasprava: vjera, hrvatstvo i demokracija. ${ }^{30}$ Časopis Luč iznosi viđenje ferijalnih sastanaka u ljeto 1908.: „(...) na kojima se bolje upoznalo i dogovorilo o zajedničkom radu u svim hrvatskim zemljama." ${ }^{11}$ Osim toga, cilj je bio provesti demokratski duh kako ne bi bilo razlike između starijih i mlađih te naposljetku svoj katolički život i vrijednosti prakticirati u svakodnevnom životu. Katolički đaci često su na kraju svojih članaka ili izvještaja koje su slali u uredništvo Luči koristili geslo: „Za vjeru i dom!“32 To je geslo označavalo identificiranje đaštva s vjerom i nacionalnim identitetom.

\subsection{Katehetski sastanak u Splitu}

Sastanak je održan 4. i 5. kolovoza 1908., dva dana nakon đačkog sastanka. Na sastanku je sudjelovalo nešto manje od stotinu sudionika: svećenika i učitelja iz Dalmacije te nekolicina njih iz Banske Hrvatske. Sastanak je također održan u Kazalištu. Skupštinu je otvorio svećenik Luka Grgić, govorom o Katekizmu kao knjižici „koje se najviše boje framasuni, liberalci i ostali protivnici vjere“. ${ }^{33}$ Sastanku je nazočio i splitsko-makarski biskup Frano Nakić, koji je zaslužan za osnivanje Sjemenišne knjižare u Splitu 1898. i Leonove tiskare 1903. godine. Ujedno, Nakić je pokrenuo katoličke novine Dan u Splitu 1903., koje su glavni izvor za proučavanje navedenih sastanaka. ${ }^{34}$

Ovaj sastanak kateheta bio je treći po redu u Splitu, ali i najbrojniji, što svjedoči o razvoju HKP-a na području Hrvatske. Ujedno, sastanak je održan u svjetlu ideja pape Pija X., koji je veliki protivnik modernizma i zalaže se za katehizaciju i borbu protiv neprijatelja koji dominira tiskom. ${ }^{35}$ Njegovo geslo bilo je: „Omnia restaurare in Christo“, tj. „Obnoviti sve u Kristu“. Upravo se ovim geslom vodi i katehetski sastanak u Splitu.

30 Vidi: Dan, god. VI, br. 31, 1908., str. 3.

31 Luč, god. IV, br. 1, 1908., str. 59.

32 Isto, str. 60.

33 Dan, god. VI, br. 32, 1908., str. 1.

34 Vidi: S. Kovačić, „Dr. Ante Alfirević - podrijetlo, školovanje i djelovanje do ulaska u Družbu Isusovu“, str. 41-42.

35 Vine Mihaljević, „Rađanje tiska Hrvatskoga katoličkog pokreta“, HKP: zbornik radova, str. 242 . 
Raspravu na sastanku otvorio je don Luka Burica temom „Vjera i slobodna škola“, pri čemu je izložio argumente kako je slobodna škola protukršćanska, ateistička i antisocijalna. Zalaže se za veću ulogu vjeroučitelja i govori kako je njihova dužnost isticanje potrebe vjere u školama. Druga točka vezuje se na prvu te ističe kako je dužnost župnika što više poučavati vjeronauk. Rezolucije donesene za prvu točku odnose se na "katehete-dušobrižnike", koji bi trebali izbjegavati sukobe s drugim učiteljima i oprezno obavljati svoju službu zbog rizika od napada neistomišljenika te s oltara upozoravati roditelje na važnost odgoja djece. Rezolucija druge točke odnosi se na suradnju samostalnog katehete i župnika te na izvješće o radu koje je kateheta dužan podnijeti svom lokalnom župniku. ${ }^{36}$ Potom je uslijedila kratka rasprava o promicanju crkvene glazbe; cilj je bio da reforma glazbe bude strogo crkvena. To se odnosilo i na sjemeništa. Među ostalim važnim odlukama prvog dana sastanka bila je odluka o osnivanju i promicanju društava sv. Cecilije ${ }^{37}$. U tu svrhu osnovani su odbori za Zadarsku nadbiskupiju te Šibensku, Splitsku, Hvarsku, Dubrovačku i Kotorsku biskupiju. Tim je zaključkom završio prvi dan katehetskog sastanka u Splitu. ${ }^{38}$

Drugi dan sastanka započinje predavanjem iz katekizma jer su na sastanak došla školska djeca iz vrličkog kotara u sklopu izleta u Split. U sklopu tog predavanja ističe se psihološka metoda poučavanja koja nalaže da se učitelj treba spustiti na razinu đaka kako bi im lakše objasnio ključne pojmove njihovim "jezikom“, tj. njihovim riječima. U prilog te metode govorio je Ferdo Heffler, ${ }^{39}$ koji kaže kako je ona polučila uspjeh u Banskoj Hrvatskoj te ju je preporučio i Dalmaciji. ${ }^{40}$ Iduća točka rasprave odnosila se na encikliku Acerbo nimis (1905.) pape Pija X., koja govori o katekizmu i o katehezi u crkvi i školi. Sljedeća točka nastavlja se na raspravu o katekizmu pa se raspravlja koji su katekizmi i tekstovi razumljiviji djeci i primjenjiviji za djecu. Smatra se da su neki tekstovi u Katekizmu zastarjeli i da je njihov jezik i stil pisanja vrlo loš. Zbog toga se otvorila oštra rasprava o austrijskom Malom Katekizmu, koji je u upotrebi u Dalmaciji. Jedni tvrde kako je loš, dok drugi smatraju da ga samo treba malo doraditi. Smatralo se da je Veliki Katekizam,

\footnotetext{
36 Isto, str. 1.

37 Sveta Cecilija zaštitnica je glazbenika i pjesnika te se njezinim imenom nazivaju glazbena društva i zborovi.

38 Dan, god VI, br. 32, 1908., str. 2.

39 Učitelj vjere i metodike na kršćanskoj učiteljskoj školi u Zagrebu. Vidi: Dan, god. V, br. 31, 1907., str. 1.

40 Dan, god VI, br. 33, 1908., str. 1.
} 
koji su sastavili austrijski biskupi po psihološkoj metodi, prikladniji za poučavanje. Na kraju rasprave predsjedatelj sastanka donio je odluku kako će oba katekizma ostati u upotrebi jer trenutno nema boljih. Tekstove u Katekizmu koji učitelji i katehete smatraju teško razumljivima za učenike, neka se ne obrađuju, tj. neka se preskoče. $\mathrm{Na}$ taj način postignut je kompromis između dviju strana. ${ }^{41}$ Zadnja točka sastanka bila je vršenje bogoštovnih čina od strane školske djece. Tu se ističe važnost tih čina u odgoju djece. Vršenje vjerskog čina preporučuje se i odraslima u Marijinim kongregacijama kao sredstvo pobožnosti. S tom točkom sastanak je zaključen te je predsjedatelj za kraj pozvao sve prisutne na sutrašnji katehetski tečaj, koji priređuju "braća iz Banovine“. ${ }^{42}$

Katehetski sastanak u Splitu ističe važnost katoličkog obrazovanja mladeži u Dalmaciji. Značajan je jer je okupio katehete iz svih dijelova Dalmacije kako bi se upoznali s novijim metodama poučavanja, tj. kako najučinkovitije poučavati djecu. Na sastanku su predstavljena iskustva kateheta iz Banske Hrvatske i njihovi rezultati poučavanja psihološkom metodom. Osim toga, važno je bilo i pitanje samog gradiva i udžbenika, kao i katekizama koji se koriste u nastavi. Cilj sastanka bio je naglasiti važnost obrazovanja te izraziti vjernost Svetoj Stolici, primjerice, uvažavanjem svih novih enciklika i učenja pape Pija X. Vidljiva je i izvrsna komunikacija između Banske Hrvatske i Dalmacije, što će dodatno biti naglašeno i na katehetskom tečaju, koji je uslijedio dan nakon završetka katehetskog sastanka.

\subsection{Katehetski tečaj u Splitu}

Početkom 20. stoljeća katehetski tečajevi bili su rijetkost $u$ Europi. Uglavnom su se održavali u Austriji i Njemačkoj. Prvi katehetski tečaj u Hrvatskoj održan je u Zagrebu u srpnju 1907. godine. ${ }^{43}$ Idući je održan 6. i 7. kolovoza 1908. u Splitu. Na tečaju u Splitu sudjelovala je i nekolicina vjeroučitelja iz Slovenije. Tečaj je započeo predavanjem "Sv. Ivan Hrisostom kao pedagog", koje je održao dr. L. Jambreković iz Zagreba. Nakon izlaganja o životu i pedagoškim metodama sv. Ivana Zlatoustog (Hrizostoma) započela je rasprava o školskim prilikama u Dalmaciji i Istri. Predavanje je održao vlč. Vicko Fulgosi iz Mravinaca, koji je ukratko opisao razvoj školstva u Dalmaciji i Istri te današnje prilike. List Dan ne donosi točno što je

\footnotetext{
41 Dan, god. VI, br. 33, 1908., str. 2.

42 Isto, str. 2.

43 Dan, god. V, br. 31, 1907., str. 1.
} 
rečeno na tom predavanju, no zaključak je da školstvo munjevito napreduje u "zadnje vrijeme". ${ }^{44}$

Zabilježen je izvrstan odaziv svjetovnih učitelja ${ }^{45}$, pri čemu predsjedatelj Jambreković izjavljuje da svećenici "rame uz rame" 46 s učiteljima moraju raditi na odgoju mladih. Nakon toga prelazi se na temu „Školske prilike u slovenskim zemljama“. O toj temi, govorio je na slovenskom jeziku kateheta Ignacij Nadrah iz Ljubljane. Glasilo Dan i opet ne donosi točno što je rečeno, nego samo da je na slovenskom jeziku pročitano izvješće o školskim prilikama na području Slovenije. Ovo predavanje označilo je završetak prvog dana tečaja. ${ }^{47}$

Drugi dan tečaja započinje predavanjem „Školske prilike u Hrvatskoj i Slavoniji“. Istaknuti su važnost i uspjeh vjerske obuke u Banskoj Hrvatskoj. Opisan je rad đačkih udruga i đačkih listova. Predavanja su obuhvatila školske prilike na području cijele Hrvatske. Katehete i svjetovni učitelji upoznali su se preko predavanja s prilikama u drugim dijelovima Hrvatske te Slovenije. Važno je ovdje naglasiti tu komunikaciju i prijenos informacija između Dalmacije, Istre, Slovenije, Banske Hrvatske i Slavonije.

Slijedi predavanje vjeroučitelja i metodičara Ferde Hefflera iz Zagreba o „pripravi katehete na djelovanje u školi, te što i kako će raditi, da mu rad bude što uspješniji“. Glavni zaključak predavanja je: „(...) da se kateheta pri obuci u vjeri ima držati što elementarnijih pojmova, kako bi bio što razumljiviji i pristupniji djeci““. ${ }^{48}$ Ovaj zaključak potječe iz već spomenute psihološke metode koju zastupa Heffler. Ključ je spustiti se do dječjih elementarnih izraza, govoriti "dječjim jezikom“. Treba probuditi zanimanje u djece preko pripovijesti. Kada vjeroučitelj obrađuje neku metodičku jedinicu, valja poučavati progresivno. Na to predavanje publika je reagirala pozitivno jer je Heffler uz teoriju osvijetlio psihološku metodu praktičnim primjerima. ${ }^{49}$

Nakon kratke stanke održano je predavanje o utjecaju profanih disciplina na vjeronauk. Glavni problem sastoji se u tome što većina kateheta ne proučava vjerski skepticizam i dvojbe koje se kod učenika javljaju na predavanjima svjetovnih učitelja. Smatra kako kateheta odmah mora reagirati i razriješiti dvojbe kod učenika nižih razreda. Predavač Eugen Kornfeind smatra kako mladež najprije

\footnotetext{
44 Dan, god. VI, br. 34, 1908., str. 1.

45 Isto, str. 1.

46 Isto, str. 1.

47 Isto, str. 1.

48 Isto, str. 1.

49 Isto, str. 1.
} 
preko malih dvojba, a potom indiferentizmom dolazi do ateizma. ${ }^{50}$ Ovo predavanje bitno je i za HKP, jer se izlaže utjecaj različitih ideja, koje djeca mogu tumačiti na svoj način i time doći do "pogrešnih" zaključaka, što vodi u sumnju u religiju općenito. Ovo predavanje „(...) pobudilo je veliko zanimanje kod slušatelja, koji su ga sa zadovoljstvom pratili, potvrdili to na koncu čestitkama i aplauzom“. ${ }^{51}$

Uz ovo predavanje veže se izvješće o opaskama vjeroučiteljima, gdje najviše griješe u obrazovanju djece. Predsjedatelj sastanka potom je izjavio kako je najvažnije da je sastanak održan kako bi se razmijenila mišljenja između kateheta, što bi u konačnici pridonijelo daljnjem razvoju školstva diljem hrvatskih zemalja. Valja istaknuti i govor velečasnog Spasoja Fabrisa o potrebi biblijskih slika u obuci vjere. Fabris smatra kako su poželjne Herderove slike, te predlaže da ih se nabavi. Zatim, preporučuje liturgijske slike za podjelu sakramenata. Osim toga, potrebno je nabaviti i kartu Palestine kod vjerske pouke. ${ }^{52}$ Potreba za nabavom navedenih stvari govori o izravnom utjecaju katehetskog tečaja na katoličko obrazovanje mladih. Uz to, time je istaknut je i kulturni karakter, koji je jedan od temeljnih polazišta HKP-a. Završne riječi sastanka odnose se na širenje katehetskog društva vodeći se slovenskim primjerom, čije katehetsko društvo broji 480 članova. Ujedno, planiran je ponovno novi katehetski tečaj, koji bi se dogodine održao u Ljubljani. Biskup Nakić predlaže odabir članova za stalni katehetski odbor za Dalmaciju. Predložen je katehetski odbor za sve biskupije u Dalmaciji. ${ }^{53}$

Katehetski tečaj u Splitu poslužio je za upoznavanje prilika i metoda poučavanja vjeronauka. Istaknuti su glavni problemi u školstvu i kod izvođenja nastave. Naglašene su glavne prepreke u kvalitetnijem obrazovanju mladih. Iz katehetskog tečaja, kao i katehetskog sastanka koji mu je prethodio, teško je utvrditi izravne posljedice i učinak koji su ostvarili katehete među učenicima. No ono što je važno naglasiti, jest napredak HKP-a u organizaciji svećenika, kateheta i đaka. Sljedeće, 1909. godine, doći će do niza katoličkih sastanaka diljem Hrvatske. Najveći broj sudionika okupit će se u Splitu (751), zatim u Zagrebu i Dubrovniku.

Cilj ovih sastanaka, uključujući i splitski đački sastanak, jest poboljšanje organizacije HKP-a održavanjem periodičnih sastanaka i naposljetku osnivanjem Hrvatskoga katoličkog đačkog saveza, koji će biti osnovan 1910., na osnovi zaključaka Sveđačkog sastanka u

\footnotetext{
50 Isto, str. 1.

51 Isto, str. 1.

52 Isto, str. 1.

53 Isto, str. 1.
} 
Splitu održanog početkom kolovoza 1909. godine. Sveđački sastanak u Splitu rezultat je navedenih ferijalnih sastanaka diljem Hrvatske pa tako i ovog opisanog đačkog sastanka u Splitu 1908. godine. Isto tako, na ferijalnim sastancima, uključujući i sastanak u Splitu, iznova je ponavljano kako je đačko gibanje na području Hrvatske kulturnog karaktera: obrazovanje, vjera, hrvatstvo, povijest (izlet u Salonu, itd.). Đaštvu je zabranjeno izravno miješanje u politiku, jer bi to izazvalo nove probleme na političkoj sceni, a bilo bi i protivno učenjima krčkog biskupa Mahnića, koji je inicijator HKP-a na području Hrvatske.

\section{OKOLNOSTI SAZIVANJA SASTANKA HRVATSKOGA KATOLIČKOG NARODNOG ĐAŠTVA U SPLITU 1909. GODINE}

Nakon uspješnog održavanja ferijalnih sastanaka diljem Hrvatske u ljeto 1908., trebalo je odlučiti što dalje s HKP-om. Naime, već 3. listopada 1908., na Skupštini HKAD-a Domagoj, pročitano je pismo prvaka HKP-a Ivana Butkovića, u kojem piše:

„Dalmatinci žele da idućih ljetnih praznika (g. 1909.) bude sastanak hrvatskoga katoličkog narodnog đaštva u Splitu, kako je to predviđeno već pretprošle godine na Trsatu. Sastanak neka bude opći (a ne pokrajinski) i dostojan našeg porasta. Jer otkad su na Trsatu udareni prvi temelji naše đačke organizacije, ona je porasla i raste sve ljepše i bolje, pa to valja pokazati u javnosti - ne zbog toga da se hvališemo i ponesemo, nego da se međusobno obodrimo i učvrstimo za daljnji rad." 54

Butkovićev prijedlog o organizaciji Općega katoličkog sastanka u Splitu prihvaćen je na sjednici HKAD-a Domagoj. ${ }^{55}$ Uz HKAD Domagoj organizatori su bili HKAD Hrvatska u Beču i Središnji odbor organizacije Hrvatskoga katoličkog narodnog đaštva u Dalmaciji. ${ }^{56}$ Ujedno, važnu ulogu u uspješnoj organizaciji sastanka odigrao je Ante Alfirević, prvak HKP-a u Dalmaciji.

HKP je početkom 1909. bio dovoljno snažan i organiziran, čemu svjedoče riječi Ivana Butkovića iz travnja iste godine:

"Val katol. pokreta preduboko je već zahvatio u srca hrv. mladeži, a da bi ga mogla kakva sila uništiti. Mladež je pokazala, da plamti žarom svojih pradjedova, da je spremna na rad i žrtve 'za

54 V. Deželić ml., Kakvi smo bili?, knjiga 1, str. 592-593.

55 Isto, str. 593.

56 S. Kovačić, „Dr. Ante Alfirević - podrijetlo, školovanje i djelovanje do ulaska u Družbu Isusovu“, str. 47. 
krst časni i slobodu zlatnu'. I na žrtve, velim, jer su mi poznate, jer sam sam gledao, koliko su pojedinci truda i vremena žrtvovali u radu za naš pokret. (...) Uopće se s našom organizacijom širi načelo, da ne će domovine spasiti vikači, nego radnici.«57

Službeni poziv na drugi sastanak hrvatskoga katoličkog đaštva objavljen je početkom srpnja 1909., a sastanak se imao održati 3. i 4. kolovoza. U splitskom listu Dan izražena je nada u uspjeh nadolazećeg sastanka, posebice zbog toga što je riječ o općem sastanku, na kojem će se okupiti katolička mladež i svećenici iz cijele Hrvatske. Nadalje, Dan piše o potrebi ovog sastanka zbog daljnjeg napredovanja i usavršavanja HKP-a. Nužnost ovog sastanka sastoji se u ostvarivanju dva cilja:

„(...) prvo, da konsolidujemo naše organizacije i precizujemo zadatak svakoga pojedinca odregjujući mu djelovanje u zajedničkog akciji; drugo, da svojim sastankom pred čitavom javnošću ponovo naglasimo naše pravo suradnje u ozdravljivanju hrvatskih jadnih prilika." 58

Splitski Dan donosi točan raspored održavanja sastanka, iz kojeg vidimo da su jednako po temama i predavačima predstavljeni svi hrvatski krajevi te Slovenija i Bosna. ${ }^{59}$ Ujedno, nakon završetka sastanka u Splitu, sudionici nastavljaju put u Dubrovnik, na Euharistijski kongres. ${ }^{60}$

Ususret sastanku (2. kolovoza) Dan izdaje poseban prilog vezan za HKP. Tako se ponovno ističu dva temeljna načela HKP-a: „Vjera i domovina, to su dvije zvijezde, dva štožera, oko kojih se okreće sav rad hrv. katol. gjaštva." $61 \mathrm{U}$ istom prilogu nalazi se članak pod nazivom „Kratka povijest hrv. kat. gjačkog pokreta“62 u kojem se potanko opisuje razvoj HKP-a. ${ }^{63}$

Važnost ovog sastanka za HKP leži ponajprije u tome što će se na sastanku okupiti više od 700 sudionika, ,480 đaka svjetovnog staleža i 271 bogoslov i klerik gimnazijalac" ${ }^{64}$ iz svih dijelova

57 I. Butković, „Glavni momenti“, str. 85-86.

58 Dan, god. VII, br. 27, Split, 1909., str. 1.

59 Vidi više: Dan, god. VII, prilog k br. 30, Split, 1909., str. 1.

60 Za sve sudionike Sveopćeg katoličkog sastanka u Splitu koji nisu iz Dalmacije organiziran je poseban parobrod, koji kreće iz Rijeke 2 . kolovoza te ujedno vraća sudionike natrag u Rijeku. Vidi više: Dan, god. VII, br. 28, Split, 1909., str. 1.

61 Dan, god. VII, prilog k br. 30, Split, 1909., str. 1.

62 Isto, str. 2-3.

63 Vidi: Isto, str. 2.

64 S. Kovačić, „Dr. Ante Alfirević - podrijetlo, školovanje i djelovanje do ulaska u Družbu Isusovu“, str. 47. 
Hrvatske, Bosne, Hercegovine i Slovenije. Na sastanku će se raspravljati o radu inteligencije u narodu, o prilikama u Banskoj Hrvatskoj, Bosni i Hercegovini te Dalmaciji, o sveučilišnim prilikama, bogoslovima i naobrazbi, srednjoškolskim prilikama, itd. ${ }^{65}$ Ujedno, sastanak je trebao riješiti pitanje daljnjeg razvoja HKP-a; o nesuglasicama koje će se u tom pogledu pojaviti bit će govora nešto kasnije u radu.

\section{SVEĐAČKI KaTOLIČKI SASTANAK U Splitu U KOlOVOZU 1909. GODINE}

Rano ujutro 2. kolovoza 1909. okupilo se u Rijeci 500 sudionika sastanka iz Banske Hrvatske, Istre, Bosne i Hercegovine te Slovenije, koji su se ukrcali na parobrod, a zatim nastavili put prema Zadru, gdje su se na brod trebali ukrcati sudionici iz sjeverne Dalmacije. Nakon dolaska u Zadar, gdje su se nakratko zaustavili, sudionike su napali zadarski Talijani; za taj su napad bili „odgovorni vogje zadarskog iredentizma“.66 Prosvjednici su bacali kamenje na sudionike sastanka, pri čemu su u čelo bili pogođeni organizator Niko Milunić i barjaktar. Parobrod je zatim krenuo prema Splitu, gdje je stigao kasno navečer. Sudionike je u Splitu dočekalo 250 katoličkih đaka. Slično kao u Zadru, bilo je i nekoliko prosvjednika koji su intonirali Marseljezu, no redarstvo ih je ubrzo privelo. Nakon iskrcavanja sudionika, povorka od 750 ljudi zaputila se prema splitskom Sjemeništu, a potom se razišla. ${ }^{67}$

\section{1. Prvi dan sastanka, 3. kolovoza 1909. godine}

Prije početka sastanka održana je sv. misa u katedrali sv. Duje, a nakon mise sudionici su se zaputili prema Kazalištu, gdje se sastanak trebao održati. Sastanak je započeo uvodnim pozdravom člana Domagoja Damjana Sokola, koji poziva na daljnji razvitak HKP-a te borbu za vjeru i domovinu. Za predsjednika Odbora izabran je Velimir Deželić mlađi, koji je potom rekao da je cilj ovog sastanka stvaranje uvjeta kako bi se hrvatski narod preporodio u Kristu. Uslijedio kratak govor načelnika Splita dr. Vicka Mihaljevića te je pročitano pismo odsutnoga splitsko-makarskog biskupa Nakića. ${ }^{68}$

\footnotetext{
65 Vidi: Dan, god. VII, prilog k br. 30, Split, 1909., str. 1.

66 Dan, god. VII, br. 31, Split, 1909., str. 1.

67 Dan, god. VII, br. 31, Split, 1909., str. 1; V. Deželić ml., Kakvi smo bili?, knjiga 1 , str. 593-594.

68 Dan, god. VII, br. 31, Split, 1909., str. 1-2.
} 
Nakon uvodnih izlaganja riječ preuzima član Domagoja Petar Rogulja, koji je govorio o „Radu inteligencije u narodu“69. Rogulja govori o praktičnom dijelu i smatra kako HKP treba čvrsto postaviti na demokratsko načelo. Potrebno je nadalje katoličko đaštvo zainteresirati za socijalna pitanja te ga uputiti na pomaganje raznim zadrugama. Rogulja se zalaže i za osnivanje pobožnih društava, kongregacija i ferijalnih društava, analfabetskih tečaja, knjižnica, itd. Ističe također i potrebu održavanja pučkih predavanja po seoskim čitaonicama i klubovima, pri čemu je ključna uloga župnika . Rogulja govori i o potrebi usavršavanja pojedinca u duhovnom i fizičkom aspektu. Pritom se referira na slovenska društva za tjelovježbu Orli ${ }^{70}$. Rogulja dodaje kako katolička mladež mora izbjegavati „strančarstvo“, ali u vrijeme izbora neka ipak podupru one koje zastupaju katolička i hrvatska načela. Za kraj dodaje kako je važno što prije osnovati „Hrvatski katolički savez“71, nalik „Slovenskoj gjačkoj svezi“. Nakon Roguljina izlaganja Slovenci su održali kratko predavanje o Slovenskoj gjačkoj svezi. Naime, cilj takvog "Saveza" bio bi socijalno obrazovanje katoličkog đaštva. ${ }^{72}$

Iz Roguljina izlaganja razvidno je kako je HKP završio svoju idejnu fazu ${ }^{73}$ te je sada vrijeme za praktično djelovanje i "omasovljavanje" HKP-a. Naime, druga razvojna faza HKP-a upravo će biti socijalna faza, u kojoj je naglasak na seljaštvo i poboljšanje njegovih uvjeta života.

Iduće izlaganje bilo je „Naša organizacija” Antuna Defara, koji je pročitao referat Ivana Butkovića, člana HKAD-a Hrvatska i jednog od prvaka HKP-a u to vrijeme. Butković poziva na čistoću katoličkih načela, koja se svakodnevno moraju provoditi u praksu te se zalaže za osnutak ferijalnih društava po svim hrvatskim pokrajinama. Za kraj dodaje kako je potrebno osnovati đački list za srednjoškolce, a taj je zadatak povjerio Domagoju. ${ }^{74}$ Nakon pročitanog referata prihvaćene su rezolucije iz Roguljina izlaganja o „radu inteligencije

69 Isto, str. 2.

70 Slična društva će se pojaviti na području Hrvatske nakon Prvoga svjetskog rata te će se unutar Hrvatskoga katoličkog pokreta razviti Orlovstvo, kao nova pokretačka sila. O Orlovstvu vidi više: J. Krišto, Hrvatski katolički pokret, str. 133-151.

71 Takav savez će biti osnovan na katoličkom sastanku u Osijeku, 23. - 24. srpnja 1910., pod imenom Hrvatski katolički đački savez; vidi: Dan, god. VIII, br. 31, str. 3; P. Grgec, Dr. Rudolf Eckert, str. 123.

72 Dan, god. VII, br. 31, Split, 1909., str. 2.

73 Više o fazama HKP-a vidi u: J. Krišto, Hrvatski katolički pokret, str. 105-106; V. Deželić ml., Kakvi smo bili?, knjiga 2, str. 756.

74 Više o osnutku novog đačkog lista za srednjoškolce vidi u: V. Deželić ml., Kakvi smo bili?, knjiga 1, str. 594-595, 617-618. 
u narodu“ i Butkovićeva kratkog referata. ${ }^{75}$ Usvojena je rezolucija o osnutku "đačkog saveza“, koji bi bio na čelu cijele đačke organizacije. Zatim je usvojena rezolucija o pokretanju lista za niže razrede srednjih škola te poziv đaštvu da se angažira oko osnivanja seljačkih omladinskih društava. ${ }^{76}$

U poslijepodnevnim satima 3. kolovoza 1909. u zgradi Kazališta su u nekoliko prostorija održani pokrajinski sastanci (banovinski, bosansko-hercegovački i dalmatinski). Tako "banovinski sastanak" primjerice govori o prilikama u Banskoj Hrvatskoj, zadaćama Domagoja i Zbora katoličke mladeži. Oba društva zagovaraju izbjegavanje „političarenja“, aktivniji rad u praksi, jaču agitaciju u "kongregacijama”, jačanje literarnog sadržaja, itd. Osim o Zagrebu tu je riječ o gradovima Zemunu, Srijemskim Karlovcima, Vukovaru, Vinkovcima, Osijeku i Požegi. Cilj je u svakoj gimnaziji osnovati Marijinu kongregaciju i pri tome katoličku đačku organizaciju. Ujedno, u svrhu promicanja srednjoškolskih katoličkih đačkih organizacija odlučeno je da se pokrene novi list za srednjoškolce pod nazivom Krijes, koji će početi izlaziti već 1909./1910. godine. Na "bosanskohercegovačkom" sastanku riječ su vodili pravnici Marko Rebac i Petar Rogulja, koji su u svojem referatu pod nazivom „Gjačke prilike" govorili o trenutnom i budućem radu na području Bosne. Obojica su svjesni kako njihov rad neće uroditi većim plodom, ali ipak im je želja poboljšati đačke prilike, što je za Bosnu izuzetno važno. U trećem i posljednjem, "dalmatinskom sastanku", koji je zapravo nastavak ferijalnog sastanka od prošle godine, izlagao je referat maturant Petani iz Zadra, pod naslovom „Naša organizacija do sada i od sada“. Referat se uglavnom svodi na prikaz razvoja katoličke đačke organizacije u Dalmaciji koja je trenutno pod vodstvom „Središnjeg centralnog odbora" u Zadru. Nakon ovog izlaganja uslijedilo je kratko izlaganje maturanta Lujaka Vicka iz Dubrovnika o stanju "naprednjaštva" u Dalmaciji. ${ }^{77}$

Nakon završetka pokrajinskih sastanaka u zgradi splitskog Kazališta uslijedio je zajednički izlet u Salonu. Izlet je bio jedna vrsta zbližavanja i razgovora o hrvatskoj katoličkoj povijesti: „Sve to samo su ruševine, puste ruševine, al te ruševine žive, govore, to su sjajna povijest, to je apologija kršćanstva. Ali to tlo nije samo kršćansko tlo, to je i hrvatsko tlo, to je središte kraljevstva hrvatskoga. "78

75 Dan, god. VII, br. 31, Split, 1909., str. 2.

76 Vidi: Dan, god. VII, br. 31, str. 6; A. Pilepić, In aedificationem, str. 7; V. Deželić ml., Kakvi smo bili?, knjiga 1, str. 594-595, 617-618.

77 Isto, str. 2.

78 Isto, str. 2. 


\subsection{Drugi dan sastanka, 4. kolovoza 1909. godine}

U jutarnjim satima (8 sati) održana je zajednička misa u crkvi franjevaca na Dobrome, a predvodio ju je dr. Fran Binički. Nakon mise ponovno su se svi okupili u zgradi Kazališta te su se podijelili u 4 skupine, koje su održale svoje sastanke: akademsko-abiturijentski, bogoslovski, srednjoškolski i sastanak preparandista. $\mathrm{Na}$ akademsko-abiturijentskom sastanku imao je glavnu riječ Ljubomir Maraković, koji je uz Butkovića vodio Luč u Beču, s temom pod nazivom „Akademičar kao katolik“. Istaknuo je važnost razvoja duševnog karaktera kod studenta, s ciljem „da bude potpun čovjek“. Nakon Marakovića riječ preuzima maturant I. Puharić iz Splita s temom „Smjer naobrazbe katoličkoga gjaka“. ${ }^{79}$

„Tri su glavna smjera naobrazbe, svakom hrv. kat. gjaku, kao budućem članu hrv. kat. inteligencije, neophodno potrebita i to: apologetski, filosofski i socijalni. Apologetski (...) koje se temelji na moderno defanzivnoj podlozi (...) Bez apologetske smo naobrazbe (...) nesreća Hrvatske. Cijeli je naš javni život, dok mu daju direktivnu naši napredni protivnici, pun logičkih protuslovlja, pun beskarakternosti: ljudi ne ćute potrebe nauke, koja uči zdravo misliti. (...) Na ustuk gojimo kršćansku filozofiju. Vjeru treba provagjati praktičnim načinom; gdje nedopremo apologetikom, ni filozofijom, prodrijet ćemo socijalnim djelovanjem na kršć. podlozi."80

Tim je izlaganjem zaključen akademsko-abiturijentski sastanak. Cilj ovog sastanka jest pripremanje budećega katoličkog đaštva kroz obrazovanje (kršćansko) i naposljetku kroz socijalni rad, tj. rad na terenu, da se stvore "potpuni ljudi", koji ce postati nositelji HKP-a.

Na bogoslovskom sastanku uvodnu je riječ imao Vinko Brajević, koji ukratko govori o važnosti bogoslova u narodu. Zatim, nakon što je proglašeno vodstvo sastanka i predsjedavatelj, riječ preuzima fra Eugen Matić ${ }^{81}$ iz Livna, koji izlaže referat pod naslovom „Bogoslov i naobrazba, osobitim obzirom na skolastičnu filozofiju“. Cilj naobrazbe bogoslova jest da se ostvari utjecaj na kulturnom polju. Ujedno, izlagač je govorio o važnosti skolastike i njezina podučavanja. ${ }^{82}$ Među ostalim izlaganjima bila su „Zajednički rad. hrv bogoslova“, "Svećenik i javnost“ i „Rad bogoslova sa svjetovnim djaštvom“. ${ }^{83}$

\footnotetext{
79 Isto, str. 2.

80 Isto, str. 2.

81 Vidi više: https://verbum.hr/autori/jenko-narcis

82 Isto, str. 2.

83 Dan, god. VII, prilog k br. 30, Split, 1909., str. 1.
} 
Ukratko, riječ je o komunikaciji bogoslova s vjernicima i katoličkim đaštvom. Što se tiče srednjoškolskog sastanka, dominirale su teme o prilikama đaštva, literarnom radu te protivnicima đaštva. A što se tiče sastanka preparandista, bila je riječ o kulturnim potrebama hrvatskoga naroda. ${ }^{84}$

U večernjim satima održana je svečana sjednica, na kojoj je govorio Ferdo Galović, s temom „Svećenik i svjetovnjak“, zatim bogoslov N. Luković, „Kršćanstvo i kultura“, a završnu riječ održao je Velimir Deželić mlađi, koji je na kraju Sveđačkog sastanka rekao: „Sa svih strana Hrvatske skupili smo se htijući da se upoznamo, da se obodrimo, da se dogovorimo i zaključimo: kako ćemo dalje raditi za vjeru i dom." ${ }^{85}$ Kad je splitski sastanak završio, sudionici su krenuli u Dubrovnik, na Euharistijski sastanak, a zatim se vratili natrag u Rijeku. ${ }^{86}$

Za splitski sastanak izdvojio bih zapažanje Jure Krište o „korijenima budućeg razdora u HKP“. ${ }^{87}$ Krišto zamjećuje kako, prema riječima člana HKAD-a Hrvatska Vlade Šprajcera, članovi HKAD-a Hrvatska nisu htjeli ovakav sastanak s mnogobrojnim sudionicima, jer su smatrali da se Pokret prebrzo proširio i da zbog toga u trenutnom stanju nije dovoljno čvrst. ${ }^{88}$ Brajević piše: „Mi smo htjeli da priredimo jedan pouzdanički sastanak, na kome bi mi među sobom ispitali temelje naše i pripravili nove puteve i kritički pregledali čitavu našu organizaciju. Većina đaštva odluči se za Spljet i mi moradosmo pristati."89 Iz ovoga možemo zaključiti kako se u tom trenutku (u kolovozu 1909.), premda je cilj bio rad na promicanju načela HKP-a, pokret raširio i učvrstio diljem Hrvatske, tj. došlo je do njegova omasovljavanja, što će u idućim godinama donijeti nove sukobe unutar HKP-a oko smjera njegova razvoja.

Nakon ovog sastanka započela je druga faza HKP-a, tj. njegova socijalna faza, koja se očituje u radu“na terenu". Naime, iz izlaganja Petra Rogulje „Rad inteligencije u narodu“ 90 jasno se može iščitati kako je sada važno što više proširiti rad HKP-a osnivanjem raznoraznih društava s ciljem obrazovanja mladeži, ali ujedno i pomoći hrvatskom seljaku da poboljša svoje materijalno stan-

\footnotetext{
84 Isto, str. 1.

85 V. Deželić ml., Kakvi smo bili?, knjiga 1, str. 593.

86 Dan, god. VII, prilog k br. 30, Split, 1909., str. 1.

87 Jure Krišto, Prešućena povijest, str. 287.

88 Usp. J. Krišto, Prešućena povijest. str. 287; Vlado Šprajcer, „1903.-1913.“, Luč, god. 7, br. 17-20, Zagreb, 1912.-13., str. 402-403.

89 V. Šprajcer, „1903.-1913.“, Luč, god. 7, br. 17-20, Zagreb, 1912.-13., str. 402-403.

$90 \quad$ Isto, str. 2.
} 
je. U sklopu pomoći hrvatskom seljaku đaštvo je pozvano „na rad oko osnivanja seljačkih omladinskih društava“. ${ }^{91}$ Ta druga faza obilježena je, osim socijalnim pitanjima, i okretanjem „narodnome jedinstvu Hrvata i Slovenaca“ te, prema tome, okretanjem,od katoličkoga aktivizma k političkomu angažiranju“. ${ }^{92}$ Stoga su se Šprajcerovi strahovi glede omasovljavanja Pokreta te time polaganog gubitka stabilnosti HKP-a ostvarili u idućim godinama. ${ }^{93}$

\section{ZAKLUUČAK}

Dalmacija se početkom 20. stoljeća, posebice grad Split, nalazi pod "opsadom" različitih liberalnih ideja koje kolaju tim prostorom. Sastanci u Splitu u kolovozu 1908. prikazuju stupanj razvoja Hrvatskoga katoličkog pokreta i svakodnevne probleme s kojima se Pokret u Dalmaciji suočava. Najveći naglasak je na obrazovanju mladeži, koja će u budućnosti biti nositelj Pokreta. Ovi sastanci su ujedno i prikaz izvanredne komunikacije katoličkih organizacija diljem Hrvatske. Najveće zasluge za to možemo pripisati đačkom glasilu Luč, ali i ostalim katoličkim novinama. Glasila su oruđe preko kojeg se prenosi i širi riječ među svim slojevima društva. Stoga se onaj tko prevlada na ovom području, može proglasiti pobjednikom.

Đački sastanak u Splitu 1908. bio je uvod i priprema za nadolazeći Sveđački sastanak koji će se održati u Splitu 1909.. Sastanak u kolovozu 1908. bio je jedna vrsta upoznavanja s problemima s kojima se đaštvo susreće svakodnevno te mogućim rješenjima tih problema. Glavni cilj sastanka je uspostava bolje komunikacije s ostalim đačkim organizacijama u Hrvatskoj. Katehetski sastanak, koji je održan samo dva dana nakon đačkog sastanka, nastavak je prošlogodišnjega katehetskog sastanka. Nastavlja se rasprava o stanju školstva i mladeži u Dalmaciji i kako poboljšati situaciju. Prisutnost Slovenaca na sastanku ukazuje na komunikaciju i razmjenu ideja. Katolička vjera zajednička je Hrvatima i Slovencima te služi kao poveznica s nacionalnim identitetom obaju naroda. Ta suradnja između Slovenaca i Hrvata unutar Katoličkog pokreta nastavit će se i u narednim godinama. Nakon završetka katehetskog sastanka uslijedio je katehetski tečaj, na kojem se ističe važnost prijenosa ideja i znanja kako bi se situacija u školstvu popravila diljem Hrvatske.

91 A. Pilepić, In aedificationem, str. 7.

92 J. Krišto, Hrvatski katolički pokret, str. 105-106.

93 Usp. V. Šprajcer, "1903.-1913.", Luč, god. 7, br. 17-20, Zagreb, 1912. - 13., str. 402-403; J. Krišto, Hrvatski katolički pokret, str. 105-108. 
Sva tri sastanka odražavaju razvoj HKP-a i njegovih kulturnih i obrazovnih komponenata. Na sastancima uopće nema riječi o političkoj borbi protiv naprednjaka. Cilj je odgojiti mladež u katoličkom duhu. To se smatra najboljim "oružjem" protiv neprijatelja Crkve. Škola je ta koja ima odgojnu i obrazovnu funkciju. U njoj se odvija kulturna borba HKP-a kako bi se zadržao hrvatski identitet: vjera (katolička), narodnost (hrvatska) i demokracija (kršćanska).

Jedan od rezultata ferijalnih sastanaka u ljeto 1908. godine jest organizacija Sveđačkog sastanka u Splitu, na kojem će se okupiti 751 sudionik, među kojima će biti čak 60 Slovenaca. Jedan od glavnih zaključaka tog sastanka je osnivanje „Hrvatskoga katoličkoga đačkog saveza“, s ciljem centralizacije katoličkog đaštva, što je provedeno iduće godine. ${ }^{94}$ Osim toga, godine 1909. započinje i osnivanje ferijalnih društava za svaku hrvatsku pokrajinu, uključujući i posebno grad Zagreb. Sveđački sastanak u Splitu u kolovozu 1909. - iako ga možemo smatrati golemim uspjehom HKP-a, ponajprije zbog broja okupljenih (750 osoba) iz svih krajeva Hrvatske, Slovenije te Bosne i Hercegovine, kao i zbog rasprava o mnogobrojnim temama koje se tiču sveučilištaraca, bogoslovlja, srednjoškolaca i preparandista valja ipak promatrati kao "dvosjekli mač". S jedne strane, HKP se u samo šest godina proširio cijelim područjem Hrvatske i djelovao na razini sveučilišta i srednjih škola, preko zajedničkoga glasila Luč; planiraju se novi listovi za srednju školu, nove kongregacije, ferijalna društva, seoske čitaonice i klubovi, rad sa seljacima s ciljem poboljšanja njihova materijalnog stanja (rad na socijalnom području) te naposljetku praksa u kojoj bi trebalo sudjelovati sve katoličko đaštvo. S druge strane, postoji opasnost od unutarnjeg rascjepa oko smjera kojim bi HKP trebao nastaviti, tj. potrebno je utvrditi koliko su temelji HKP-a stabilni u danom trenutku. Naime, početkom školske godine 1909./ 10. Ivan Butković i Ljubomir Maraković (uz Mahnića vođe HKP-a), napuštaju HKAD Hrvatska u Beču. Tim činom nastupa nova generacija HKP-a, koja treba odrediti sljedeći korak cjelokupnog Pokreta. Na sastanku u Splitu preko predavanja Petra Rogulje doznajemo da je idejna faza HKP-a završena te je vrijeme za početak socijalne faze i rada "na terenu" cjelokupnog đaštva i vodstva HKP-a, što istovremeno implicira "omasovljavanje” Pokreta. Stoga završetak Sveđačkog sastanka u Splitu označava početak nove faze razvoja Hrvatskoga katoličkog pokreta. 


\section{CATHOLIC MEETINGS IN SPLIT IN AUGUST OF 1908 AND 1909}

\section{Summary}

The paper presents the development of the Croatian Catholic Movement until September 1909, with special emphasis on the Catholic meetings held in Split in August in year 1908 and 1909. Three different meetings were held in Split in August in year 1908. The first meeting was the Catholic Student Meeting which was also held in the summer of 1908, besides Split, in Zagreb, Trsat, Đakovo and Travnik. The second meeting refers to the Catechetical Meeting at which the state of education in Dalmatia was discussed and how to solve the catechists and pastors' daily problems in the field of education. The third meeting was the Catechetical Course organized by pedagogues and catechists from northern Croatia, where the course participants were introduced to new teaching methods. In addition to the theoretical part, the way of functioning of new teaching methods in practice was also presented. These meetings were an introduction to the General Student Catholic Meeting, which took place in the summer of 1909 in Split and brought together 751 participants from all over Croatia, Slovenia and Bosnia and Herzegovina. The paper pays special attention to the importance of the General Student Catholic Meeting and evaluates it in the broader context of the Croatian Catholic Movement. The importance of this meeting lies in the fact that it marked the beginning of a new phase of the Catholic Movement in Croatia, i.e. the Movement is becoming "massified". The main source for the production of this paper is the Catholic newspapers Dan [Day], which was published in Split from 1903-1918.

Key words: Croatian Catholic Movement, Split, Student and Catechetical Meeting, Catechetical Course, General Student Catholic Meeting 